\title{
Study on Selection of Equity Incentive Models by Chinese Private Listed Companies
}

\author{
Yu Jiamei \\ School of Economics, Shanghai University, Shanghai, China \\ shirelyahead@163.com
}

Keywords: equity incentive mechanism, stock option, restricted shares

\begin{abstract}
Principal-agent problems including information asymmetry, moral hazard and adverse selection were caused by separation between modern enterprise ownership and right of management. These problems were alleviated to a certain degree with the birth of equity incentive mechanism. Due to the short development history of equity incentive mechanism in our country, domestic scholars have different opinions on the selection, formulation, implementation and effect of equity incentive mechanism, and there was no consistent conclusion on how to select an equity incentive mechanism which is suitable for an enterprise. In this article, I compared and studied the selection preference on equity incentive mechanism of private companies in our country from the angle of company growth and financial index and put forward some suggestions on equity incentive mechanism.
\end{abstract}

\section{Introduction and Literature Review}

\subsection{Introduction}

The study on the governance practice of western companies and modern enterprise theory has proven that equity incentive as an important means of managing a company can resolve well the problem of agent inspiration and realize long-term inspiration to professional managers. The exploration practice on equity incentive has experienced four high tides in our country, with the birth and development of new China capital market, the main practice group during the previous three practices was state-owned enterprise, but it failed or suspended in the end, while the fourth high tide comes with the launch of China Growth Enterprise Market and private companies become the main practice group. Therefore, how to formulate an incentive mechanism which meets national conditions and is suitable for the operation of listed companies in China and how to make it become an effective means for reform and development of our listed companies have become a problem which is worthy of being studied and resolved continually by scholars and businessmen.

\subsection{Literature Review}

Different equity incentive mechanisms have different influences on the effectiveness of enterprise, some people think that stock option incentive plan is more advantageous to improve the management benefit of enterprises, some people think that restricted stock incentive plan is more effective, and some people think that a composite pattern is of more long-term significance. Chen Tian (2010) thought, in terms of the time span, the composite model of equity incentive plan is of more long-term incentive effect, and it can combine both long-term interests and short-term interests, and can promote sustainable growth of the company's performance, and can bring value-added benefits for employees and boost the value of the company at the same time. Su Cuifei (2014) said that for enterprises of the start-up period and the growth period, they have a broad prospects for development, so appropriate equity incentive can arouse the enthusiasm of managers, promote them to work hard, and thus quickly occupy the market and improve the enterprise value; for companies of mature period, equity incentive plays a limited role. 


\section{Equity Incentive Relevant Theories}

\subsection{Principal-agent Theory}

After observing that there is a large disadvantage on the fact that the enterprise owner acts as a company manager at the same time, in 1930s, American economists Burleigh and Means put forward "Principal-agent Theory" and advocated separation between the ownership and right of management, the enterprise owner should reserve residual claimant rights and transfer the management right. "Principal-agent Theory" has already become the logic starting point of modern company governance. This theory has resolved problems brought by separation between enterprise ownership and right of management.

\subsection{Human Capital Management}

Human Capital Management originated from economic studies. In 1960s, American economist Schurz and Becker created this Human Capital Management theory, which opened up a brand-new thought on the production capacity of human. According to this theory, it is said that physical capital referred to material products, including workshop, machine, equipment, raw materials, land, currency and other negotiable securities; while human capital is the capital reflected on human itself, that is the summation of expenditures on education and professional training spent on the producers and the opportunity cost when receiving education, which is reflected as the reserve summation of various production knowledge, working and management skills as well as physical constitution .

\subsection{Two Factor Theory}

It is also called as "motivation-health theory", which was put forward by American psychologist Herzberg in 1959. Relevant factors in enterprises can be divided into two types, that is, satisfactory factors and unsatisfactory factors. Satisfactory factors refer to the factors which can make people obtain satisfactory and motivation. Unsatisfactory factors refer to the ones which are liable to cause different opinions and negative behaviors that is health theory. He thought these two factors are the main factors which would affect the staff's working performance. The theory of health includes company's policy and management, supervision, salary, relationship with the colleagues and working conditions and so on. Motivation factors are related to work or working content, including achievement, appreciation, significance and challenge of working itself, sense of responsibility as well as promotion and development. If these factors are met, great motivation would be brought to people.

\subsection{Equity Incentive Models}

In our country, the commonly adopted equity incentive models include stock option, restrict stock, stock appreciation right and performance stock, in which the most commonly used ones by our private listed companies are stock option model and restrict stock, and these two models are also the main research points of this article.

\section{Research Hypothesis and Design}

Different equity incentive models have different characters and applicable conditions, the listed companies should select a suitable equity incentive model which can give full play of the company value. Among our listed companies, private companies are the main force, currently, two models of stock options and restrict stock are the two main incentive models, and a handful of companies adopt the combination way of two models. However, which factors should be considered by the listed companies when they make a decision on which equity incentive model? In this article, what-if analysis and positive inspection would be carried out to factors which would affect the selection of different equity incentive models. 


\subsection{Research Hypothesis}

Hwang\& Lilien (2000)discovered that for companies which are in the rapid development stage, selecting stock option model can improve the company value more effectively compared with restrict stock; meanwhile according to the analysis of the above theory, it is found that enterprises in high-speed growth period have a high demand in cash, while stock option could bring larger incentive effect at a lower cost, compared with stock option, the restrict stock model is more able to reserve talents, which could increase the incentive object's opportunity cost of leaving the company. Therefore, restrict stock model is more suitable for companies which are in slow growth period or mature period. Therefore, the following hypothesis is put forward:

Under equivalent conditions, companies with higher growth possibility prefer to select stock option type incentive model, while companies staying at mature period or slow growth period prefer to select restrict stock model.

\subsection{Research Design}

\subsubsection{Data source and sample selection}

During 2010 and 2014, there were 481 private listed companies announced equity incentive plans (draft), after deleting abnormal indexes and missing data, 455 sample data were obtained in total. And relevant data originated from database of Tai'an and RESSET financial research database and data was processed by SPSS20.0.

\subsubsection{Variable Design}

1) Explained variable

In this article, selection of equity incentive models by our private listed companies was studied, so the explained variable is equity incentive model.

2) Explaining variable

According to the above hypothesis made to the selection of equity incentive model by private listed companies, the following variables are selected to explain.

Company Growth (GR), Cash Flow condition (CF) ,Earning Power (ROE) , Liability Level (DEBT)

\subsubsection{Regression Model Construction}

For the study on the factors affecting equity incentive models, stock option model is defined as $\mathrm{MODE}=1$, restricted stock model is defined as $\mathrm{MODE}=0$, so Binary Logistics regression model is selected in this article. The model is constructed as below:

$\mathrm{MODE}=\beta+\beta_{1} \mathrm{SIZE}+\beta_{2} \mathrm{IND}+\beta_{3} \mathrm{GR}+\beta_{4} \mathrm{OW}+\beta_{5} \mathrm{OC}+\beta_{6} \mathrm{CF}+\beta_{7} \mathrm{DEBT}+\beta_{8} \mathrm{ROE}+\beta_{9} \mathrm{IB}+\beta_{10} \mathrm{PLU}+\varepsilon$

Converted into Logistic type:

$$
\begin{array}{r}
\operatorname{Logit}(\mathrm{P})=\operatorname{Ln}(\mathrm{P} / 1-\mathrm{p})= \\
\beta+\beta 1 \mathrm{SIZE}+\beta 2 \mathrm{IND}+\beta 3 \mathrm{GR}+\beta 4 \mathrm{OW}+\beta 5 \mathrm{OC}+\beta 6 \mathrm{CF}+\beta 7 \mathrm{DEBT}+\beta 8 \mathrm{ROE}+\beta 9 \mathrm{IB}+\beta 10 \mathrm{PLU}+\varepsilon
\end{array}
$$

In which, $\beta$ is a constant term, $\beta_{\mathrm{i}}(\mathrm{i}=1,2, \ldots . .10)$ is a coefficient, $\varepsilon$ is an error term.

As shown in the table 1.

Table 1 Time Distribution of Equity Incentive Plans (draft) Announced for the First Time

\begin{tabular}{|l|l|l|l|l|l|}
\hline Year & $\begin{array}{l}\text { Planned } \\
\text { Quantity }\end{array}$ & $\begin{array}{l}\text { Stock } \\
\text { Option }\end{array}$ & $\begin{array}{l}\text { Restrict } \\
\text { Stock }\end{array}$ & $\begin{array}{l}\text { Stock } \\
\text { Appreciation } \\
\text { Right }\end{array}$ & $\begin{array}{l}\text { Combination } \\
\text { Model }\end{array}$ \\
\hline 2010 & 66 & 50 & 12 & 1 & 3 \\
\hline 2011 & 120 & 77 & 35 & 1 & 7 \\
\hline 2012 & 113 & 44 & 51 & 1 & 17 \\
\hline 2013 & 147 & 34 & 90 & 1 & 23 \\
\hline 2014 & 594 & 252 & 256 & 4 & 82 \\
\hline
\end{tabular}




\begin{tabular}{|l|l|l|l|l|l|}
\hline 总计 & 594 & 252 & 256 & 4 & 82 \\
\hline
\end{tabular}

Note: ST and delisted companies which have bad performance have been deleted from this research data.

Table 2 Distribution of Equity Incentive Plans Announced for the First Time

\begin{tabular}{|l|l|l|l|}
\hline Year & Planned Drafts & Stock Option & Restricted Stock \\
\hline 2010 & 55 & 43 & 12 \\
\hline 2011 & 105 & 72 & 33 \\
\hline 2012 & 94 & 46 & 64 \\
\hline 2013 & 110 & 34 & 83 \\
\hline 2014 & 481 & 239 & 242 \\
\hline Total & 481 & 239 & 242 \\
\hline
\end{tabular}

Note: the study objects of this article are two types of incentive models of stock option and restrict stock, therefore, stock appreciation right and combination models were deleted, and listed companies which adopted different equity incentive models during 2010-2014 were deleted.

According to the above table 2, the quantity of the listed companies which launched and implemented equity incentive plans was rising steadily, in the other hand, as two main incentive models, the stock option and restrict stock models showed different trends of change. The quantity of restrict stock model kept rising gradually and reached to 242 in 2014 and exceeded the quantity of stock option model; while the application of stock option showed a declining trend and only took up $23 \%$ of the total quantity in 2014.

Table 3 Analysis on the year when the equity incentive plans are implemented

\begin{tabular}{|l|l|l|l|}
\hline Year & Implemented plans & Stock option & Restrict Stock \\
\hline 2010 & 22 & 11 & 11 \\
\hline 2011 & 34 & 16 & 18 \\
\hline 2012 & 56 & 10 & 46 \\
\hline 2013 & 58 & 7 & 51 \\
\hline 2014 & 49 & 3 & 46 \\
\hline Total & 219 & 47 & 172 \\
\hline
\end{tabular}

According to the above table 3, among the implemented equity incentive plans, the restrict stock took up $78 \%$ of the total number, while the number of incentive plans of stock option model implemented was less.

\subsubsection{Descriptive statistical analysis}

According to the below table 4, the maximum value of the average growth rate (GR) of the total asset during the recent two years for the companies in the overall sample reached 2.856, the maximum average value of net cash flow of business activities of each share (CF) during the recent two years reached 1, the maximum liability level (DEBT) reached 0.9172 and the maximum earning power (ROE) reached 37.5. Therefore, the mean values of the asset-liability ratio, net return on assets as well as cash flow all indicate that the overall business condition of the listed companies which announced equity incentive plans was good.

Table 4 Descriptive Statistic

\begin{tabular}{|l|l|l|l|l|l|}
\hline & $\mathrm{N}$ & $\begin{array}{l}\text { Minimum } \\
\text { value }\end{array}$ & $\begin{array}{l}\text { Maximum } \\
\text { value }\end{array}$ & Mean value & $\begin{array}{l}\text { Standard } \\
\text { deviation }\end{array}$ \\
\hline GR & 455 & -0.1084805 & 2.8563590 & 0.430282851 & 0.5051019452 \\
\hline CF & 455 & 0 & 1 & 0.74 & 0.439 \\
\hline DEBT & 455 & 0.007521 & 0.917268 & 0.34198774 & 0.193727522 \\
\hline ROE & 455 & -0.9005 & 37.500 & 10.61135 & 6.995156 \\
\hline
\end{tabular}

In order to better compare differences between listed companies which selected stock options and listed companies which selected restrict stock, descriptive statistic was conducted by classifying the sample into two categories, see the below table 5 and 6 for details. 
According to the table 5 and table 6, it is found that among listed companies which announced equity incentive plans, in terms of company growth, the mean value, maximum value and minimum value of listed companies which selected stock option model were all obviously larger than that of the companies which selected restrict stock model, which indicated that companies with good growth preferred to select stock option model; in terms of earning power, the mean value, maximum value and minimum value of listed companies which selected restrict stock were all obviously larger than that of the listed companies which selected stock options, which indicated that companies which had strong earning power or ROE preferred to select restrict stock model.

Table 5 Descriptive Statistic on Stock Option Model

\begin{tabular}{|l|l|l|l|l|l|}
\hline & $\mathrm{N}$ & $\begin{array}{l}\text { Minimum } \\
\text { Value }\end{array}$ & $\begin{array}{l}\text { Maximum } \\
\text { Value }\end{array}$ & Mean Value & $\begin{array}{l}\text { Standard } \\
\text { Deviation }\end{array}$ \\
\hline GR & 224 & -0.0766540 & 2.8563590 & 0.539663783 & 0.6089502971 \\
\hline CF & 224 & -3.110 & 5.920 & 0.22750 & 0.892528 \\
\hline DEBT & 224 & 0.007521 & 0.917268 & 0.35184863 & 0.217134303 \\
\hline ROE & 224 & -9.005 & 33.145 & 11.07460 & 7.061732 \\
\hline
\end{tabular}

Table 6 Descriptive Statistic on Restrict Stock Model

\begin{tabular}{|l|l|l|l|l|l|}
\hline & $\mathrm{N}$ & $\begin{array}{l}\text { Minimum } \\
\text { Value }\end{array}$ & $\begin{array}{l}\text { Maximum } \\
\text { Value }\end{array}$ & Mean Value & $\begin{array}{l}\text { Standard } \\
\text { Deviation }\end{array}$ \\
\hline GR & 231 & -0.1084805 & 1.8808015 & 0.324216491 & 0.3480154429 \\
\hline CF & 231 & -1.980 & 2.460 & 0.33197 & 0.629827 \\
\hline DEBT & 231 & 0.031868 & 0.765858 & 0.33242567 & 0.167877142 \\
\hline ROE & 231 & -5.975 & 37.5 & 10.16213 & 6.915628 \\
\hline
\end{tabular}

\section{Conclusion and Suggestions}

\subsection{Study Conclusion}

This article took listed companies which announced equity incentive plans during 2010-2014 as sample, and analyzed the selection of equity incentive plans by private listed companies in our country, the following conclusions are obtained:

(1) With the rules and regulations on equity incentive in our country becoming improving and complete constantly, since 2011, the number of listed companies which announced equity incentive plans increased significantly, and the number of restrict stock application increased rapidly and exceeded the number of stock option application, and the number of listed companies which adopted the combined two models was also increasing gradually.

(2) Enterprise growth is one of factors affecting the selection of equity incentive model by the listed companies in our country, and the enterprises staying at high-speed growth period prefer to select stock option incentive model.

(3) Enterprises with weak ROE prefer to select stock option model, although this conclusion is not consistent with the previous hypothesis, given features of some industries which require a growth space for the company's share price under the profit pressure, stock option incentive is able to bring attractive high benefit to the motivated objects

\subsection{Suggestion: Seeking for Optimum Incentive Model which is Suitable for Enterprises}

Designing an optimum incentive model is an important factor to improve the implementation effect of equity incentive. The optimum incentive model is able to connect enterprise, capital market and manager market together organically. According to the analysis on empirical findings, when selecting the equity incentive models, enterprises should mainly consider about the growth and development period and establish an effective internal governance mechanism to make the equity incentive plan be implemented successfully by combing relevant factors including accountant and tax influence. 
Stock option is a better choice for enterprises staying at a high-speed growth period, high-speed growth would be bound to cause a rise in stock price in the future. Stock option is able to well combine the future benefits of the motivated objects and the stock price fluctuation, which would guarantee the strength of equity incentive. Meanwhile, high growth would be bound to cause limited liquid capital and stock option model is able to reduce the cost of incentive, which would guarantee the investment made by the enterprises to the cost of scientific research to a great extent. Restrict stock is good for motivating the managers to focus on the realization of long-term strategic targets, meanwhile, the incentive cost is lower, only after realizing the strategic target, the motivated objects are able to obtain benefits. Therefore, restrict stock incentive model is suitable for enterprises which are staying at the start-up period with insufficient cash flow and need stable talents urgently, so that the benefit of the core technicians and business can be tied with that of the company owner.

\section{References}

[1] Luo Song, Beijing Technology and Business University, Development Progress and Problem Analysis on Equity Incentive System in Our Country

[2] Huang Jiaming and Fang Weidong, Transaction Cost Theory: From Coase to Williamson, Journal of HFUT (Hefei University of Technology) (Social Science Edition), M, $1^{\text {st }}$ Edition, Volume 14, March, 2000

[3] Tang Shuo, Empirical Study on Influence brought to Enterprise Investment by Equity Incentive from the Perspective of Growth, 2009

[4] Wang Yanru, Study on Factors Affecting the Selection of Equity Incentive Model in Manufacture Industry, Chinese Certified Public Accountant, 2013(09):32-28

[5] Lv Changjiang etc. Design on Equity Incentive System of Listed Companies: is it incentive or welfare? Management World, 2009(09):138-147 